\title{
Evaluation of phosphorus and nitrogen balances as an indicator for the impact of agriculture on environment: A comparison of a case study from Poland and Mississippi US*
}

\author{
Renata Gaj ${ }^{1}$, Nacer Bellaloui ${ }^{2 \#}$ \\ ${ }^{1}$ Department of Forestry Natural Foundation, Faculty of Forestry, Poznan University Life of Sciences, Poznan, Poland; \\ ${ }^{2}$ Crop Genetics Research Unit, United States Department of Agriculture-Agricultural Research Service (USDA-ARS), Stoneville, \\ USA; ${ }^{\#}$ Corresponding Author: nacer.bellaloui@ars.usda.gov
}

Received 10 November 2011; revised 12 December 2011; accepted 20 January 2012

\begin{abstract}
The objective of this research was to quantify the changes of nitrogen $(\mathrm{N})$ and phosphorus $(\mathrm{P})$ balances in Poland and Mississippi (MS), USA. Nutrient balances were calculated as difference between input and output in the agricultural system according to Organisation for Economic Cooperation and Development (OECD) methodology. A positive nutrient balance means that $a$ potential environmental problem may result from that nutrient; a negative nutrient balance means there is a potential yield loss. The $N$ and $P$ soil surface balances for Poland and MS were calculated for the year 1998 through 2008. The results showed that both MS and Poland had positive $\mathbf{N}$ and $\mathbf{P}$ balances, indicating that there was a surplus of $N$ and $P$. The average balance for $\mathrm{N}$ was $48 \mathrm{~kg} \cdot \mathrm{ha}^{-1}$ in Poland and $102 \mathrm{~kg} \cdot \mathrm{ha}^{-1}$ in MS. For $P$, it was $3 \mathrm{~kg} \cdot \mathrm{ha}^{-1}$ in Poland and $19 \mathrm{~kg} \mathrm{P}$ $\mathrm{kg} \cdot \mathrm{ha}^{-1}$ in MS per cultivated area. This research demonstrated that the nutrient balance of $\mathbf{N}$ or $\mathbf{P}$ depended on the efficient use of each nutrient and type and source of fertilizer used. This research is significant for $\mathbf{N}$ and $\mathbf{P}$ fertilizer management and their impact on agriculture production and environment health.
\end{abstract}

Keywords: Nitrogen; Phosphorus; Nutrient Efficiency; Nutrient Availability; Nutrient Budget

\section{INTRODUCTION}

Crop production requires an adequate supply of nutri-

*Mention of trade names or commercial products in this publication is solely for the purpose of providing specific information and does not imply recommendation or endorsement by the US Department of Agriculture. ents. Cassman [1] showed the complex relationship between nutrient availability, crop yield, nutrient efficiency, and the challenge to meet food demand, while protecting natural resources. The increase in the US population over the past 50 years has led to high food demand, additional wastewater treatment, higher fossil fuel burning, and expanding urban environments. Intensive agriculture generally leads to imbalances in nutrient budget, and these imbalances have shifted in scale from local to regional to continental dimensions during the last decades, especially for $\mathrm{N}$ and $\mathrm{P}$ [2]. There are many ways in which agricultural operations can reduce the amount of nutrients released from farm fields. This can be achieved by applying nutrients at the proper rate and time, with the appropriate application method and appropriate nutrient forms. For example, Wiesler and Armbruster [3] reported that one way to reduce nutrients runoff is to reduce nutrients applied to the field.

For sustainable agriculture, efficient $\mathrm{N}$ use is a major task to ensure economically and environmentally sound food production. In sustainable agriculture, the supply of nutrients must be precisely adjusted to the crop demand. A surplus of nutrients poses potential threats to the environment, including the contamination of surface and ground waters with phosphates and nitrates, and contamination of air with $\mathrm{NH}_{3}$ and $\mathrm{NO}$. Although $\mathrm{N}$ and $\mathrm{P}$ are essential nutrients for plant growth and feed nutrition quality, excessive amounts of $\mathrm{N}$ and $\mathrm{P}$ as supply or runoff become problematic. The artificial production of nitrogen fertilizers has grown exponentially since the 1950 s and will continue to grow into the foreseeable future without a significant change in demand and use [4]. Protection of agricultural lands is primarily meant to maintain and increase soil fertility, i.e., the physical, chemical, and biological properties which allow high crop yield and quality. Numerous studies have shown that 54\% - 
$72 \%$ of mineral fertilizer applied is taken up by the plant, $8 \%-21 \%$ is bound with the soil organic matter, $2 \%-$ $18 \%$ is lost to the atmosphere by denitrification, and only $2 \%-8 \%$ is lost by leaching [5]. Although increased leaching loss of nitrate can result from rainfall and irrigation without plant cover, less water percolates through heavy soils than through light soils, resulting in lower nitrate losses from heavy soils [6]. This indicates that leaching of nutrients depends on biotic (vegetation, soil microorganism, and others) and abiotic (soil type, rate of applied fertilizers, and others) environmental factors.

One of the common methods of evaluating nutrient release from the field surface is the nutrients balance as proposed by Organisation for Economic Cooperation and Development (OECD) [7-10]. The soil surface budget approach potentially produces interesting information for a more efficient use of fertilizers and animal manure for different crops [11]. OECD approach was based on the use of environmental indicators, developed by the OECD and USDA-NRCS, that can be used to identify and quantify the impact of agricultural management on the environment, and track the effects of policy measures. OECD member states are required to keep records of nutrient surpluses and deficits from agriculture on an annual basis [12]. The balance proves the proper mineral nutrient management and the important indexes of agricultural environment. Based on the above discussion, it is clear that fertilizer use and its impacts on agricultural production, environment nutrient surplus, and nutrient deficits are still a challenge. Therefore, the main objectives of this research were: 1) implementation of OECD surface $\mathrm{N}$ and P balances for Poland and Mississippi (MS); 2) determination of the changes in national nutrient budgets with increasing industrialization and changes in cropping systems; and 3) assessment of nitrogen and phosphorus efficiency.

\section{MATERIALS AND METHODS Nitrogen Balance Using OECD Method}

The N gross soil surface balance for Poland and Mississippi are calculated from 1998 to 2008 as the difference between the total quantity of nitrogen inputs entering the soil and the quantity of nitrogen outputs leaving the soil annually. Methodology for calculating soil nutrient balance has been developed by OECD and adopted by Eurostat [7]. In this paper, we are using modified versions of the so called "soil surface balance". The difference between input and output gives a balance surplus or deficit expressed in kg per total area or per ha of agricultural land. Therefore, nitrogen loss directly from livestock (e.g. ammonia volatilization from stored manure) is not included in the balance. Variables required for the calculations of the national gross $\mathrm{N}$ soil surface balance are the following: mineral and organic fertilizer, livestock manure, biological $\mathrm{N}$ fixation, seeds and planting material, and the total harvested crops and fodder. The main source of statistical data for nitrogen and phosphorus fertilizers consumption from 1998 to 2008 years were International Fertilizer Association and Statistics (IFADATA) [13]. Average N and P fertilizer consumption per hectare was calculated by dividing total consumption of $\mathrm{N}$ and $\mathrm{P}$ for a given country and year by the total agriculture area. Data referring to total agricultural area and wheat production in the studied period were obtained online [14]. Statistical yearbooks provide the most reliable information about $\mathrm{N}$ and $\mathrm{P}$ consumption at the country level. All statistical livestock and crop production data needed to be converted into $\mathrm{N}$ equivalents which allow summation of the total amount of $\mathrm{N}$ inputs and outputs and nutrient balance. To convert the various variables from their original recorded unit into common unit, $\mathrm{N}$ coefficients were used. Polish $\mathrm{N}$ and American coefficients were derived from Institute of Soil Science and Plant Cultivation (IUNG-PIB, Pulawy) and USDANRCS, respectively. Some of the coefficients used for the national balances were provided by OECD. Table 1 shows the coefficients used to calculate the total harvested $\mathrm{N}$ from cereals. Additional data for atmospheric deposition was derived from long term trends in deposition loads of air pollutants in Poland and was set to $17 \mathrm{~kg}$ $\mathrm{N} \cdot \mathrm{ha}^{-1}$. Data in nutrient balance were based on agricultural land use area $(\mathrm{AL})$.

The estimate of annual total quantity of nitrogen balance includes mineral nitrogen fertilizer: quantity consumed by agriculture; net livestock manure nitrogen production: total numbers of animals (cattle, pigs, sheep, goats, poultry and horses) in different categories according to species multiplied by respective coefficients of the quantity of nitrogen contained in manure/animal/year; atmospheric deposition of nitrogen (AD): total agricultural land area multiplied by a single coefficient of nitrogen deposited $(\mathrm{kg} / \mathrm{ha})$; biological nitrogen fixation (BNF): area of harvested legume crops multiplied by respective coefficients of nitrogen fixation plus the nitrogen fixation by free living soil organisms computed from the total agricultural land area multiplied by a coefficient of nitrogen fixation $(\mathrm{kg} / \mathrm{ha})$; nitrogen contained in seeds and planting materials (S\&P): quantity of seed multiplied by respective coefficients of nitrogen content per $\mathrm{kg}$ of seeds [15]. The annual total quantity of nitrogen outputs or nitrogen uptake includes harvested crops, which is the quantity of harvested crop production multiplied by respective coefficients of nitrogen uptake; and forage crops, which is the quantity of forage crop production e.g. fodder beets, hay, silage and pasture multiplied by respective coefficients of nitrogen uptake. Nitrogen use efficiency (NUE) was measured as the percentage ratio of total ni- 
Table 1. Nitrogen coefficient to calculate the total harvested $N$ from cereals and other crops.

\begin{tabular}{|c|c|c|c|}
\hline \multirow{2}{*}{ C211 Codes used in the OECD national nitrogen balances } & \multirow{2}{*}{ Crop } & \multicolumn{2}{|c|}{$\mathrm{N}$ coefficient $\left[\mathrm{kg} \cdot \mathrm{mg}^{-1} \cdot \mathrm{N}\right]$} \\
\hline & & Poland & US \\
\hline $\mathrm{C} 2112$ & Winter Wheat & 20 & 17 \\
\hline $\mathrm{C} 2112$ & Rice & - & 10 \\
\hline $\mathrm{C} 2113$ & Coarse Grains & & \\
\hline $\mathrm{C} 21131$ & Barley & 16 & 19 \\
\hline $\mathrm{C} 21132$ & Maize & 15 & 14 \\
\hline C21139 & Other Coarse Grains & & \\
\hline $\mathrm{C} 21191$ & Triticale & 18 & - \\
\hline $\mathrm{C} 2119$ & Other Cereals & 17 & 19 \\
\hline $\mathrm{C} 212$ & Total oil crops & & \\
\hline $\mathrm{C} 2121$ & Soybeans & - & 59 \\
\hline $\mathrm{C} 1124$ & Rapeseed & 34 & 35 \\
\hline $\mathrm{C} 113$ & Total Root Crops & & \\
\hline $\mathrm{C} 1131$ & Potatoes & 3 & 4 \\
\hline $\mathrm{C} 1132$ & Sweet potatoes & - & 3 \\
\hline $\mathrm{C} 215$ & Total Fruits & 2 & 2 \\
\hline $\mathrm{C} 216$ & Total Vegetables & 3 & 3 \\
\hline $\mathrm{C} 217$ & Total Industrial Crops & & \\
\hline $\mathrm{C} 21711$ & Sugar Beet & 2 & 9 \\
\hline $\mathrm{C} 21712$ & Sugar Cane & - & 5 \\
\hline
\end{tabular}

Notes: Minus (-) means data not available; OECD = Organisation for Economic Cooperation and Development.

trogen uptake by crops and forage (tones) to the total nitrogen available from fertilizer, livestock manure, and other nitrogen inputs (tonnes).

\section{RESULTS AND DISCUSSION}

Nearly $60 \%$ of Poland land is devoted to agriculture, and arable land and grassland account for $18 \mathrm{M}$ ha. During 11-year period, the agricultural land use, including arable land, permanent crop land, and permanent pasture, was reduced by $12 \%$ in Poland and $5.3 \%$ in Mississippi (Figure 1). Mississippi has more than $12 \mathrm{M}$ ha of land, the majority of which $(61 \%)$ is forested. Pasture and cropland uses account for an additional $27 \%$ of the land. Large scale agricultural production predominates, with most acreage in soybeans, corn, and cotton. In the last decade, Mississippi witnessed changes in cultivated plants (increasing the area of corn grown for energy and decreasing the area of cotton). The great increase in corn area was noted in 2007, and in comparison to year 2006, it was almost 3 times greater, meanwhile the area of cot- ton decreased by $50 \%$ in 2008 . In Poland, crop production for energy is a newly developing practice, and the largest area of arable land in Poland is grown for cereals, oilseed rape, and feed plants. In 2008, cereals covered $73 \%$ of the arable land [16]. In Poland, the changes in the structure of cultivated crops rely on the increase of area

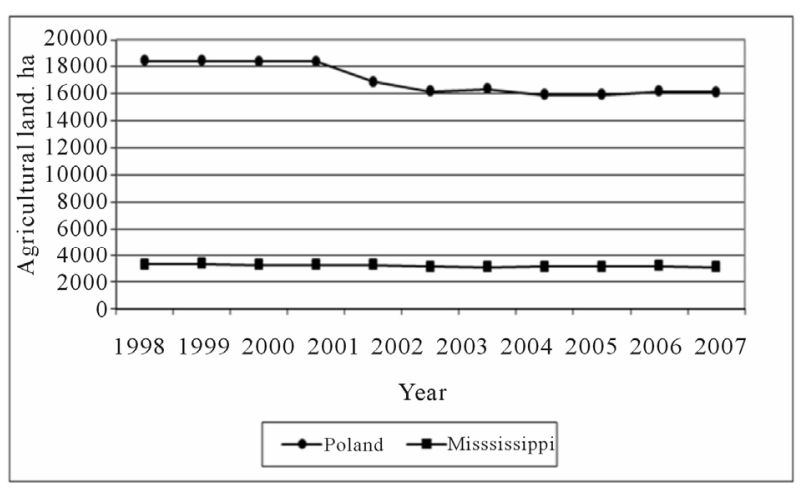

Figure 1. Changes of the agricultural land (AL) for Poland and Mississippi from 1998 to 2008. 
with corn and oilseed rape, and on the decrease of area with potatoes, sugar beets, and forage crops. Wheat, corn, and oilseed rape are the most fertilized crops in Poland. Because of the importance of these crops per unit cultivated area and associated economic yield, the use of fertilizers may involve a high risk of environmental contamination.

The differences in agricultural production between Mississippi and Poland can be explained by soil quality and environmental differences. The average quality of Polish soils is rather low because of their origin, dominated by acid soils with low content of colloids, clay minerals and humus. The soils of Mississippi are much better quality, especially in Mississippi River valley known as Mississippi Delta. The higher fertility of soils in this region is often associated with flood. Poland and MS have different soils and climatic conditions, and also different farm size. Most farms in Poland are small and semi-subsistence farms of 1 - 5 ha [5], especially in the eastern part of the country, as Poland was never fully collectivized pre-1990. These farms use a minimum of purchased farm inputs (e.g. fertilizers, pesticides, energy and water), and farm income is insufficient to support modernization of the farming enterprise. The average farm size in Mississippi is more than 110 ha. Differences in soil management and farm structure would affect nutrients use and supply, and consequently nutrient balance.

\subsection{Nitrogen Input and Output}

The main nitrogen and phosphorus inputs consisted of mineral fertilizers and manure. Nitrogen input in Poland and Mississippi consists of mineral nitrogen fertilizers and organic fertilizers (Figure 2). The inorganic fertilizers and the nutrient content of livestock manure together comprise around $77 \%$ of nitrogen inputs for Poland and $82 \%$ for Mississippi (Figure 2). In Poland the use of nitrogen fertilizers per ha is higher than in US, although the yield is similar, $3.3 \mathrm{t} \cdot \mathrm{ha}^{-1}$ in US in 2009. The winter wheat grain yields in Poland are low in respect to potential yields. According to Central Statistical Office, average wheat grain yield in Poland in years 1998-2008 was $3.5 \mathrm{t} \cdot \mathrm{ha}^{-1}$. In 2004, the average yield reached the level of $4.3 \mathrm{t} \cdot \mathrm{ha}^{-1}$. Unfortunately, in the following 3 years the average yield was much lower. The much lower production potential in Poland and other European countries can be partly explained by soil and climate condition [17]. For example, the greater change in nitrogen input in dry springs in 2006, 2007, and 2008 showed that the main nitrogen source was from mineral nitrogen fertilizers. The use of mineral nitrogen fertilizers in Poland from 1998 to 2008 ranged between 40 to $71 \mathrm{~kg} \cdot \mathrm{N}$. However, in Mississippi during the same period, nitrogen fertilizer ranged between 30 to $39 \mathrm{~kg} \mathrm{~N} \cdot \mathrm{ha}^{-1}$. It is important to

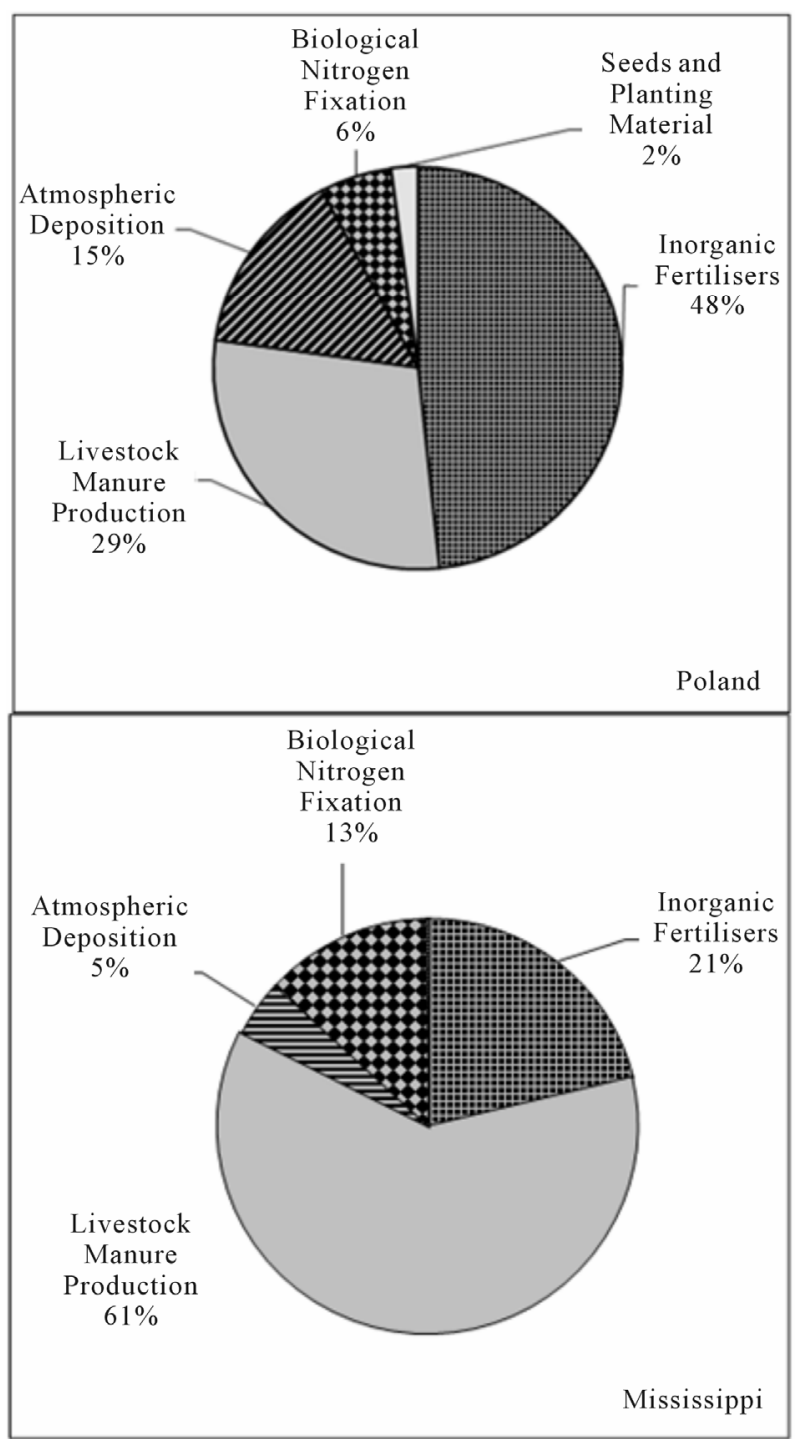

Figure 2. Proportional share of $\mathrm{N}$ input variable to the $\mathrm{N}$ balance (average 1998 to 2008) in Poland and Mississippi.

report that great changes in the use of nitrogen fertilizers were observed just before and after Poland became a part of European Union (EU). The increase of nitrogen use is associated with EU financial support for agricultural development. This trend is still greater in regions with intensive plant and animal production. Lower level of nitrogen fertilizer use in Mississippi can be explained by the greater soybean production area (about $36 \%$ of cultivated area of Mississippi is soybean) and nitrogen input from poultry production. A greater contribution of pig production in Poland was positively correlated with grain production, that is a main forage source. Animal production in Poland shows significant local differences, especially in Wielopolska and Podlasie regions. In contrast to Poland, MS uses $61 \%$ of nitrogen input as natural organic fertilizers, mainly poultry. Cattle and pigs are the 
major contributors input variables in animal production in Poland, while intensive poultry production accounts for most of the manure stocks in MS. Poultry manure contributes $61 \% \mathrm{~N}$ as input to the balance (Figure 2). Cattle are primarily pastured in Mississippi. Average nitrogen use per ha in MS is more than 3 times higher than in Poland reaching $108 \mathrm{~kg} \cdot \mathrm{N} \cdot \mathrm{ha}^{-1}$ (Figure 2). Nitrogen is also added to agriculture from atmospheric deposition (AD), seed and plant material (S\&P), and nitrogen biological fixation processes (BFN). Nitrogen deposition is accounted by a constant factor, and the $\mathrm{N}$ input from biological $\mathrm{N}$ fixation and seed and plant material contributes a small amount on average (Figure 2). The harvest of crop and removal of crop residues are major mechanisms of nutrient removal. In Poland, the greatest nitrogen removal with yield was with grains and pastures. The percentage contribution of these crops to nitrogen removal is equal to $41 \%$ and $27 \%$ to $\mathrm{N}$ balance (Figure 3). In MS the contribution percentages of nitrogen removal were the highest in pastures $50 \%$ and oil crops $33 \%$ and lowest in industrial crops (Figure 3).

\subsection{Phosphorus Input and Output}

The principal sources of $\mathrm{P}$ inputs in Poland and MS derive from phosphorus fertilizers $(96 \%)$ and from livestock manure (99\%), which together comprise around 96\% and 99\% of P inputs respectively (Figure 4). Main phosphorus sources are mineral phosphorus fertilizers, and its contribution to phosphorus input in Poland was 51\% (Figure 4). Between 1998 and 2005, the use of phosphorus fertilizers in Poland was $7.2 \mathrm{~kg} \cdot \mathrm{P} \cdot \mathrm{ha}^{-1}$. The trend of phosphorus fertilizers use has been increasing since 2005, and in 2008 reached $40 \%$ (Figure 5). The phosphorus fertilizers consumption per ha, as in the case of nitrogen, was dependent on region and ranged from $6 \mathrm{~kg}$ in Podkarpatian to $12 \mathrm{~kg}$ in Opole region. As in the case of nitrogen, the important source of phosphorus input is natural organic fertilizers $(45 \%$ of total $\mathrm{P})$. The greatest phosphorus amounts are associated with pig production $(43 \%)$ and poultry production $(20 \%)$. There was a positive correlation between phosphorus balances and input (Table 2).

In MS, $81 \%$ of phosphorus is derived from organic fertilizers, and only $18 \%$ from phosphorus mineral fertilizers (Figure 4). The average mineral fertilizers use was $5 \mathrm{~kg} \cdot \mathrm{P} \cdot \mathrm{ha}^{-1}$, meanwhile the average amount of phosphorus used from organic fertilizers was $24 \mathrm{~kg} \cdot \mathrm{P} \cdot \mathrm{ha}^{-1}$. Main source of phosphorus among organic fertilizers, as in nitrogen, is poultry production, and more than $80 \%$ of phosphorus is degraded by precipitation [18], part is taken-up by microorganisms, and the other part is bound with organic compounds [19]. It is clear that the change of consumption level of mineral and organic $P$ fertilizers

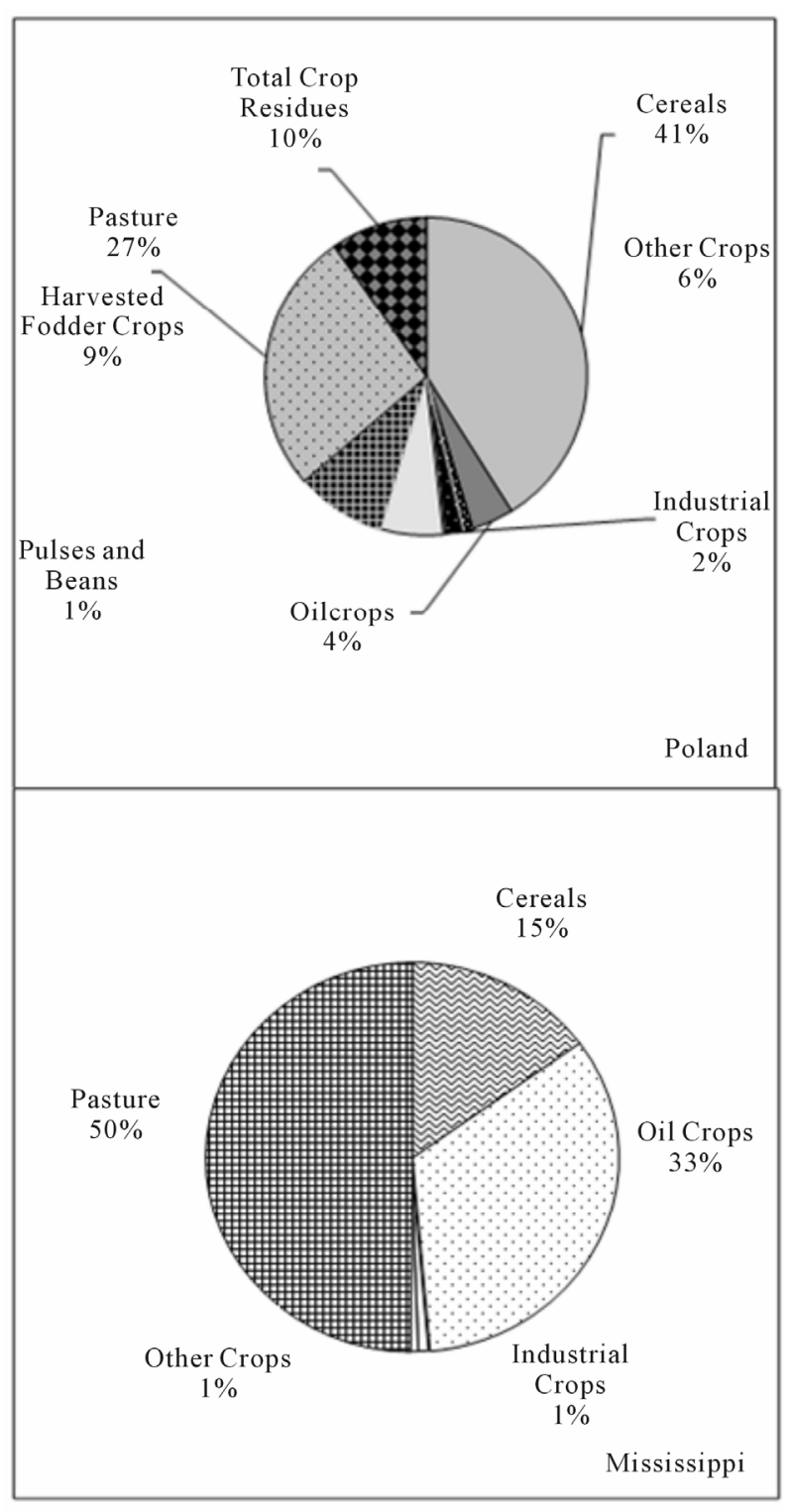

Figure 3. Proportional share of $\mathrm{N}$ output to the $\mathrm{N}$ balance (average 1998 to 2008) in Poland and Mississippi.

for Poland showed that mineral $\mathrm{P}$ fertilizers are used at higher rate across years $\left(\mathrm{R}^{2}=0.8055\right)$ than organic fertilizers $\left(\mathrm{R}^{2}=0.7521\right)$ (Figure 5). In Poland, the greatest phosphorus amounts were removed by grain yields, meanwhile in MS the greatest amounts of phosphorus were removed by oil crops and corn harvesting (Figure 6).

\subsection{Gross Soil Surface Nitrogen and Phosphorus Balance in 1998-2008}

Gross nutrient balances provide useful information about nutrient use in an agriculture system, changes in environmental quality, and sustainability in soil nutrient resources and agriculture production. Nutrient balance estimates surplus or deficit of input to output in a given 
Table 2. Correlation coefficients between phosphorus balances and input variables.

\begin{tabular}{ccccccccc}
\hline Country & $\begin{array}{c}\text { Inorganic } \\
\text { Fertilisers }\end{array}$ & Cattle & Pigs & $\begin{array}{c}\text { Sheep and } \\
\text { Goats }\end{array}$ & Poultry & $\begin{array}{c}\text { Other } \\
\text { Livestock }\end{array}$ & $\begin{array}{c}\text { Atmospheric } \\
\text { Deposition }\end{array}$ & $\begin{array}{c}\text { Seeds and } \\
\text { Planting Material }\end{array}$ \\
\hline Poland & $0.763^{*}$ & $-0.611^{*}$ & 0.565 & -0.291 & $0.766^{*}$ & -0.680 & $-0.729^{*}$ & $-0.729^{*}$ \\
Mississippi & 0.341 & $0.647^{*}$ & -0.461 & - & $-0.658^{*}$ & - & 0.517 & -0.509 \\
\hline
\end{tabular}

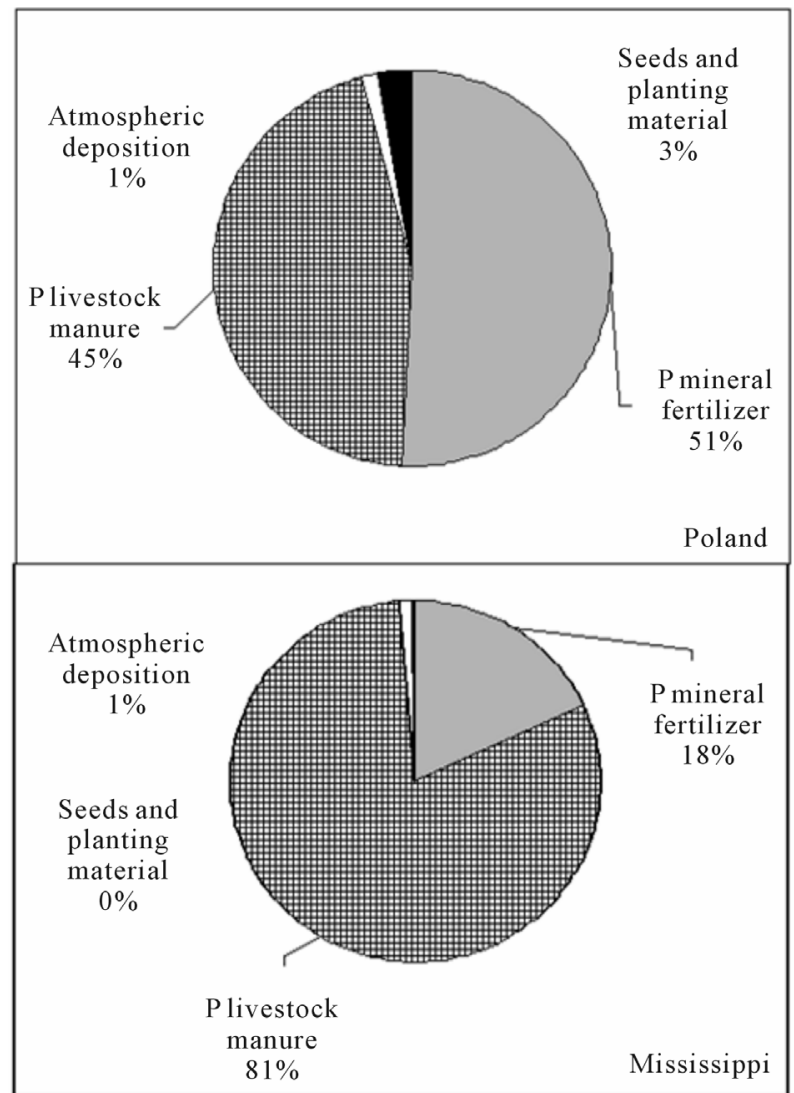

Figure 4. Proportional share of $\mathrm{P}$ input variable on the $\mathrm{P}$ balance (average 1998 to 2008) in Poland and Mississippi.

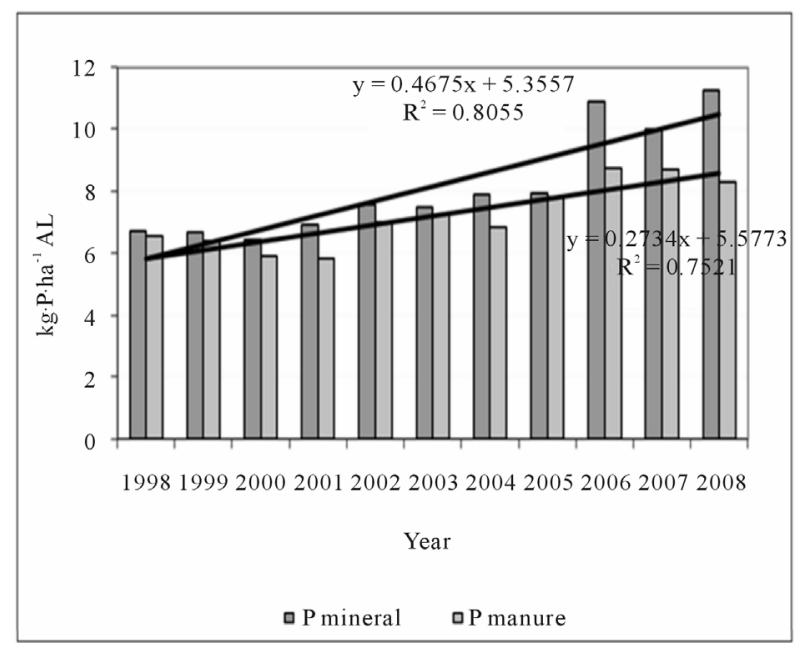

Figure 5. Changes of consumption level of mineral and organic phosphorus fertilizers for Poland from 1998 to 2008.

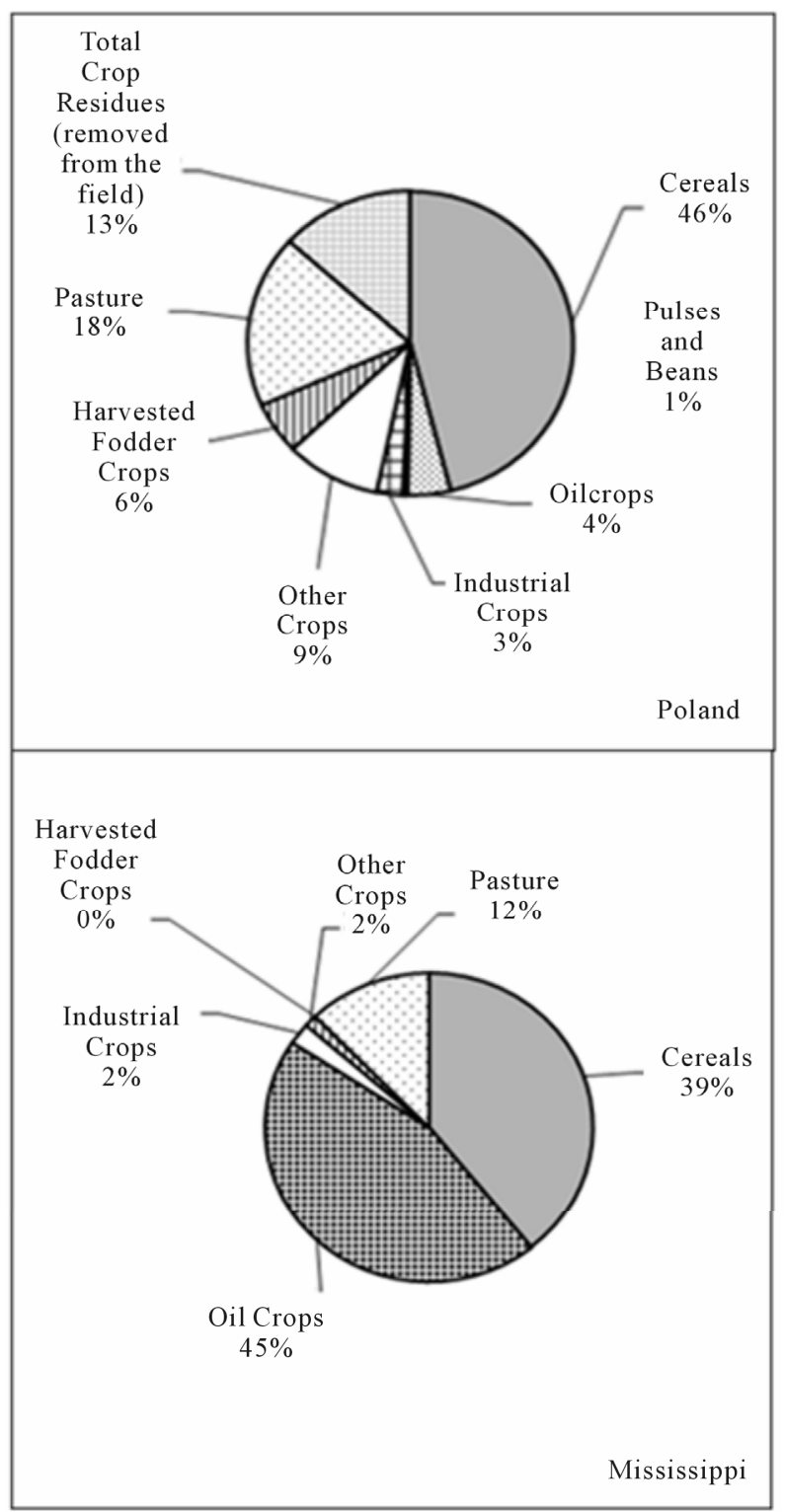

Figure 6. Proportional share of $\mathrm{P}$ output on the $\mathrm{P}$ balance (average 1998 to 2008) in Poland and Mississippi.

agriculture system. A continuous surplus of a nutrient balance in $\mathrm{N}$ or $\mathrm{P}$, for example, indicates potential environmental problem. However, continuous deficit indicates potential sustainability problem in production. Therefore, a proper agricultural management practices is based on nutrient balance that shows whether there is surplus or deficit. Therefore, the nutrient balance is a 
main index of sustainable agricultural practice [15,20]. In case of phosphorus, the balance does not explain the role of this nutrient in agricultural production, but is used for quantative description of appearance. Fundamental differences between $\mathrm{N}$ and $\mathrm{P}$ dynamics in soil and their mobility through the landscape, therefore govern the time scales over which surpluses of $\mathrm{N}$ and $\mathrm{P}$ become important [21]. The nitrogen and phosphorus balances were positive for Poland and Misssissippi. A nutrient surplus occurs when the quantity of a nutrient applied in fertilizers is greater than that removed during harvest. The trends in the intensity of nutrient surpluses per hectare of total farmland, both of $\mathrm{N}$ and $\mathrm{P}$ over the period from late 1998 to 2008 fluctuated considerably. Nutrient balance has increased in Poland since 1994 by $56 \mathrm{~kg}$ $\mathrm{N} \cdot \mathrm{ha}^{-1}$. For both countries nitrogen balance shows surpluses, but higher for MS than Poland (Figure 7). Nitrogen balance is mostly affected by amount of mineral fertilizer and manure application. The information provided by $\mathrm{N}$ balances is used to analyse the interactions between agriculture and environment and to evaluate the impacts of agricultural policy on the environment [22]. A nutrient surplus is the best indicator of total nutrient losses to environment if integrated over a relatively a long period [21]. The correlation analysis of nitrogen balance in US and Poland shows the importance of pig production in Poland and poultry production and atmospheric deposition in MS (Table 3).

The regression analysis shows that in Poland the change of nitrogen balance in $99.8 \%$ of the time is described by regression equilibrium (1)

$\mathrm{Y}(\mathrm{N}$ balance $)=-2($ Nmin. Fert. $)+4(\mathrm{~N}$ Cattle $)+8(\mathrm{~N}$ Pigs $)$ +326 (N Sheeps) - 46(N Poultry) - 74(Other) $-19(\mathrm{BNF})$ $+20(\mathrm{~S} \& \mathrm{P})+6210031, \mathrm{R}^{2}=99.8 \%$ dla $\mathrm{n}=11, \mathrm{p}<0.05$.

National average $\mathrm{N}$ surplus in 1998-2008 was 49 $\mathrm{kg} \cdot \mathrm{N} \cdot \mathrm{ha}^{-1}$, nearly one-quarter of agricultural land had a surplus greater than $50 \mathrm{~kg} \cdot \mathrm{N} \cdot \mathrm{ha}^{-1}$ (Figure 7). Despite the relatively low rates of use of fertilizers, the nutrient balances show surpluses. This is explained by the generally low crop yields. The annual nitrogen surpluses show a slight increasing trend in Poland and declining trend in MS. Evident trend of increasing nitrogen balance in Poland was observed after 2004. In the 2004-2008 in Poland, there was shown a rising trend of nitrogen soil surface balance as a result of intensive crop production measured by level mineral nitrogen fertilizer use. In the last four years the surplus of nitrogen balance increased by about $55.4 \%$ and coefficient of use efficiency by $55 \%$ (Figure 8). Nitrogen surplus per hectare of agricultural land is variably sub-national. During last 4 years the greatest increase of nitrogen balance greater than 80 $\mathrm{kg} \cdot \mathrm{ha}^{-1}$ of cultivated area was noted in 2 regions: $\mathrm{Ku}-$ jawskjo-Pomorskie and Wielkopolska. Simultaneously in

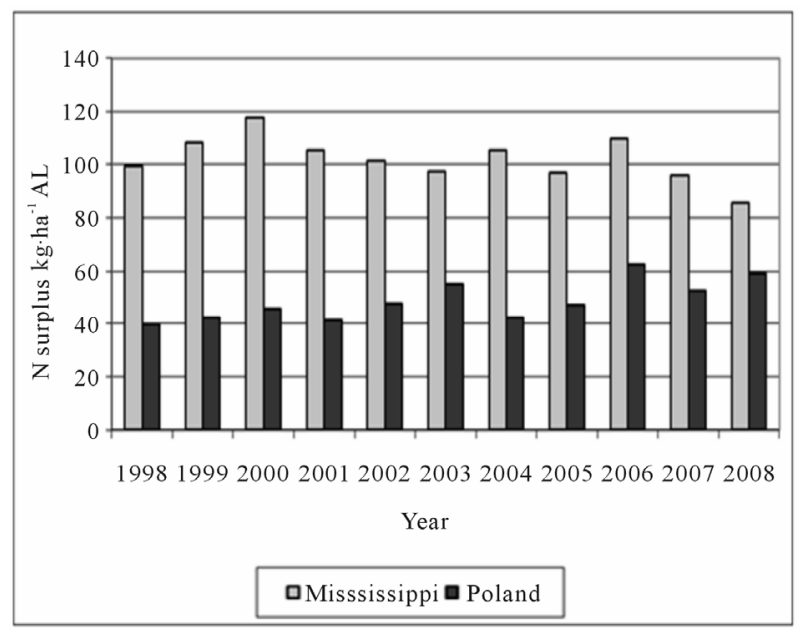

Figure 7. Soil surface $\mathrm{N}$ balance for Poland and Mississippi 1998 to 2008 calculated according to the OECD method.

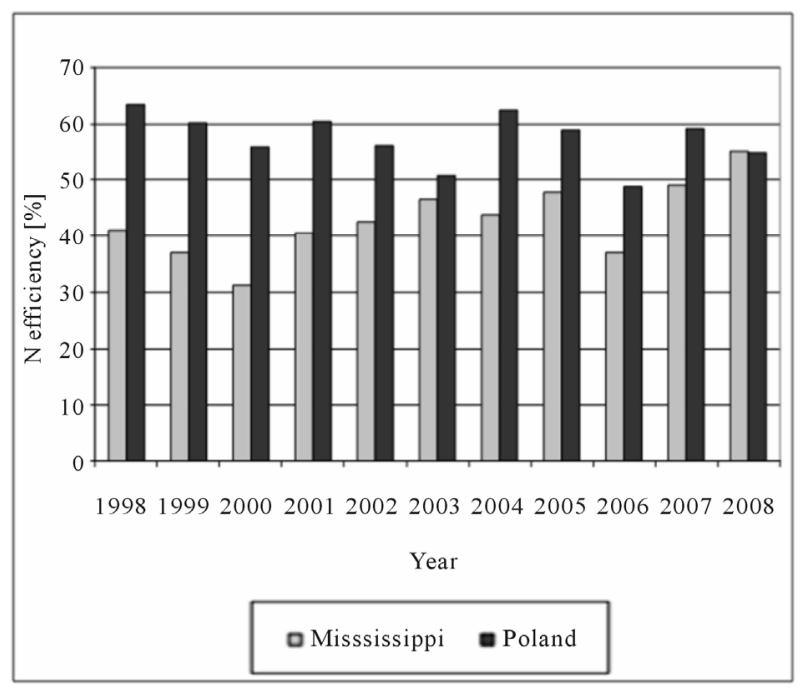

Figure 8. Changes of coefficient nitrogen use efficiency (NUE), $\%$ in Poland and Mississippi.

Table 3. Correlation coefficients between nitrogen balances and input variables.

\begin{tabular}{|c|c|c|c|c|c|c|c|c|c|}
\hline Country & $\begin{array}{l}\text { Inorganic } \\
\text { Fertilisers }\end{array}$ & Cattle & Pigs & $\begin{array}{l}\text { Sheep and } \\
\text { Goats }\end{array}$ & Poultry & $\begin{array}{c}\text { Other } \\
\text { Livestock }\end{array}$ & $\begin{array}{l}\text { Atmospheric } \\
\text { Deposition }\end{array}$ & $\begin{array}{c}\text { Biological } \\
\text { Nitrogen } \\
\text { Fixation }\end{array}$ & $\begin{array}{c}\text { Seeds and } \\
\text { Planting } \\
\text { Material }\end{array}$ \\
\hline Poland & 0.515 & -0.262 & $0.605^{*}$ & -0.059 & 0.254 & -0.372 & -0.385 & -0.370 & -0.445 \\
\hline Mississippi & -0.160 & 0.428 & -0.413 & - & $-0.698^{*}$ & - & $0.700^{*}$ & -0.063 & -0.295 \\
\hline
\end{tabular}


these regions relatively low index of nitrogen use was noted $45 \%$ and $48 \%$ respectively. In the two other regions extremely low nitrogen use was noted (30 and 17 $\mathrm{kg} \cdot \mathrm{N} \cdot \mathrm{ha}^{-1}$ ) (Dolnośląskie and Podkarpackie regions) (Figure 9). Na- tional nutrient balances are much less powerful indica- tors than regional nutrient balances. Although the na- tional balance is at a reasonable level, there may still be a risk of leaching at regional or local levels, for example, in areas with high livestock densities [23]. The $\mathrm{N}$ bal- ances are mostly affected by amount of mineral fertilizer and manure application. Problems of N surplus are also associated with rising animal stocking densities and structural changes in the livestock industry toward large confined operations, especially for pigs, poultry and to lesser extent dairy cattle [22,24]. In the United States, for example, with the growing number and size of confined livestock operations, over $60 \%$ of manure is produced on farms that have insufficient land to fully absorb the waste.

Environment protection in Poland is regulated by many international agreements and with EU law. One of the recent HELCOM reports shows that total $\mathrm{N}$ and $\mathrm{P}$ loads entering the Baltic Sea from Poland increased to 152,600 tonnes and 10,230 tonnes, respectively [25]. Poland is bound by international environmental agreements limiting emissions of nutrients into the Baltic Sea, ammonia, methyl bromide and greenhouse gases [26]. The EU Nitrates Directive $\mathrm{N}$ dictates that on agricultural land, application of $\mathrm{N}$ as animal manures should not exceed $170 \mathrm{~kg} \cdot \mathrm{N}$ per ha. Therefore, optimal fertilizer nitrogen management practices are crucial for an efficient

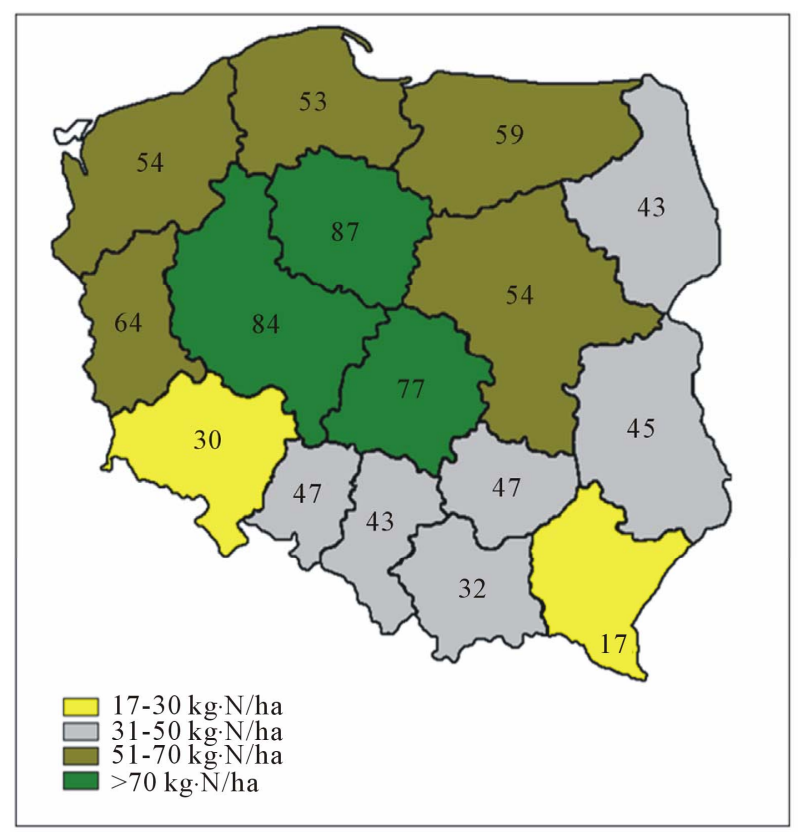

Figure 9. Gross nitrogen balance at the regional level for Poland (average 2005-2008). agricultural production for mitigation of $\mathrm{N}$ losses to the environment (leaching and thus eutrophication of surface and groundwater, gaseous losses) [27].

According to Fotyma and Igras [28], the loss of nutrients from agriculture in Poland depends on the geographic area and its soil properties because of big share of small size farms. For example, precipitations fluctuates from 500 to above $850 \mathrm{~mm}$, depending on years and regions. The average losses of nitrogen by leached nitrogen from the agricultural area are estimated at $11 \mathrm{~kg} \cdot \mathrm{N} \cdot \mathrm{ha}^{-1}$ year. On average $\sim 11 \mathrm{~kg} \cdot \mathrm{N}$ is leached from 1 ha area of cultivated land. Due to the regional differences in production types and natural conditions, the environmental impact of agriculture also varies considerably within the country. A major mechanism of $\mathrm{N}$ loss in Mississippi is denitrification in waterlogged soils. As the water content of soils increases, the amount of air in soils decreases. Conditions necessary for denitrification are waterlogged soils, carbon sources for use by the an aerobic microbes, and as either $\mathrm{NO}_{3}^{-}$or $\mathrm{NO}_{2}^{-}$. The rate is greatly accelerated by higher temperature. Nitrogen transformations depend on soil moisture conditions, soil acidity, temperature, and microbial activity. Because the Mississippi climate is characteristically warm and humid, microbial transformation occurs throughout most of the year. This extended period of decomposition results in lower organic matter levels in Mississippi soils than in cooler, drier climates. The loss of nitrogen via denitrification in Mississippi deltaic-estuarine and wetland environments can be as high as $21-36 \mathrm{~g} \cdot \mathrm{N} \cdot \mathrm{m}^{-2} \cdot \mathrm{yr}^{-1}$ [29]. Rick et al. [30] showed that in Louisiana denitrification rates increase with increasing temperature and high nitrate concentrations. Soil denitrification reduces nitrate to nitrogen gas that is returned to the atmosphere. Low oxygen levels occur most often under condition of high soil water content and soil temperatures exceed $10^{\circ} \mathrm{C}$. National nutrient balance indicators can mask important regional (sub-national) variations across a country, especially where more intensive agricultural production systems are spatially concentrated in a small part of the overall agricultural land area. Nitrogen balance appears to be a rather useful indicator of $\mathrm{N}$ leaching over longer periods of time [31].

Reductions in N and P surpluses alone will not be sufficient and their relative importance for combating environmental problems must be assessed in relation to other forms of loss and land use management. The sustainable agriculture accepts the maximal use of nutrient from fertilizers and minimal nutrient losses to the environment. The amount of nutrients taken up and fertilizers use should be replaced and necessary nutrients are required for nutrient balance for expected yields [32]. Phosphorus balance for Poland and MS shows, as in case of nitrogen, positive balance (Figure 10). The balance values in 


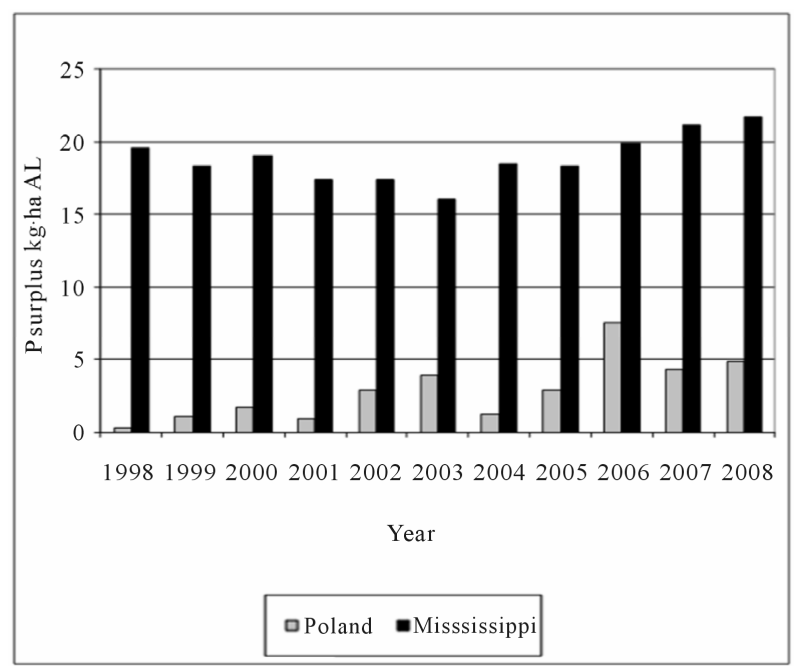

Figure 10. Gross phosphorus balance at the regional level for Poland and Mississippi.

1998 was $3 \mathrm{~kg} \cdot \mathrm{P} \cdot \mathrm{ha}^{-1}$ for Poland and $19 \mathrm{P} \cdot \mathrm{kg} \cdot \mathrm{ha}^{-1}$ for MS. By 2008, $\mathrm{P}$ balance in Poland reached about 5 $\mathrm{kg} \cdot \mathrm{P} \cdot \mathrm{ha}^{-1}$, but in MS it was about $22 \mathrm{~kg} \cdot \mathrm{P} \cdot \mathrm{ha}^{-1}$. There was signifi- cant positive correlation between phosphorus mineral fertilizer and $\mathrm{P}$ balance, and between $\mathrm{P}$ fertilizer from poultry and $\mathrm{P}$ balance (Table 2). A negative correlation was found between phosphorus balance and cattle or- ganic fertilizers, between P balance and atmospheric de- position, and between $\mathrm{P}$ balance and seed and plant materials.

In MS, the P balance was positively correlated with the cattle manure $\mathrm{P}$ and negatively correlated with poultry manure $\mathrm{P}$. The regression analysis showed that $76 \%$ of the change of $\mathrm{P}$ balance in Poland was derived from mineral fertilization, meanwhile in MS was derived from poultry manure. Significant correlation between the nutrient balance and the input and output of nutrients are shown in Tables $\mathbf{4}$ and $\mathbf{5}$. The regression analysis showed that $\mathrm{P}$ balance changes in Poland of $90 \%$ was derived from cereals P, oilseed rape P, and fodder crops P (Eq.2). Meanwhile, in MS P was derived from cereals (Eq.3).

$\mathrm{Y}(\mathrm{P}$ balance PL $)=0.190($ Cereals $)+0.191(\mathrm{OSR})+$ $0.133(\mathrm{FC})+325430 \mathrm{R}^{2}=0.903 ; \mathrm{n}=11 ; \mathrm{p}<0.00063$. (2)

$\mathrm{Y}(\mathrm{P}$ balance MS $)=-2.57$ (Cereals $)+83966 \mathrm{R}^{2}=0.80$; $\mathrm{n}=11 ; \mathrm{p}<0.00017$.

Based on the literature, $\mathrm{P}$ losses from soil profile are low, $0.4-0.5 \mathrm{~kg} \cdot \mathrm{ha}^{-1} \cdot \mathrm{year}^{-1}$, and are bigger in acid and very acid soils during high rainfall. The evaluation of the available P in Poland and MS shows that in both countries the soil contains sufficient level of available P. On average, the contribution of very rich soil in Poland to $\mathrm{P}$ is $34 \%$ [33] and in MS is $80 \%$.

Johnston and Dawson [34] stated that P run-off to surface waters is due to soil erosion. The run-off of soluble $\mathrm{P}$ compounds in soil profile is very low and the $\mathrm{P}$ is transported with mass flow of soil particles. According to Igras [35] the amount of phosphorus transported from mineral soils during year is lower than $1 \mathrm{~kg} \cdot \mathrm{P} \cdot \mathrm{ha}^{-1}$.

\subsection{Nitrogen and Phosphorus Use Efficiency}

Inefficient nutrient use and concomitant nutrient enrichment of agro-ecosystems have contributed to agriculture impact on aquatic systems [36]. Nitrogen use efficiency (NUE) is another agro-environmental indicator used in agro-policy and provides information about the relative utilization of additional $\mathrm{N}$ applied to an agricultural production system of a country and region. Production of economically profitable and high quality yield of cultivated plants depends on the nitrogen fertilization rate. Nitrogen use efficiency during the 11 year period was higher in Poland than in Mississippi for most years (Figure 9). The average value of nitrogen use in this period was $57 \%$ for Poland and $42 \%$ for MS. Trends in overall $\mathrm{N}$ use efficiency (i.e. the ratio of $\mathrm{N}$ output to $\mathrm{N}$

Table 4. Correlation coefficients between balance nitrogen and variables of output.

\begin{tabular}{cccccccc}
\hline Country & Cereals & Oil crops & Pulses and Beans & Industrial Crops & Other Crops & Harvested Fodder Crops & Pasture \\
\hline Poland & $-0.668^{*}$ & 0.254 & -0.377 & -0.544 & -0.499 & -0.16 & $-0.618^{*}$ \\
Mississippi & $-0.642^{*}$ & $-0.869^{*}$ & - & 0.437 & $-0.752^{*}$ & 0.577 & $-0.801^{*}$ \\
\hline
\end{tabular}

Notes: " means significant at $\mathrm{p} \leq 0.05$; “-” means data not available; $\mathrm{n}=11$.

Table 5. Correlation coefficients between phosphorus balances and output variables.

\begin{tabular}{ccccccc}
\hline Country & Cereals & Oil crops & Industrial Crops & Other Crops & Harvested Fodder Crops & Pasture \\
\hline Poland & 0.078 & 0.435 & 0.487 & 0.481 & $0.783^{*}$ & 0.533 \\
Mississippi & $-0.898^{*}$ & $-0.715^{*}$ & $0.697^{*}$ & $-0.730^{*}$ & 0.176 & 0.352 \\
\hline
\end{tabular}

Notes: "means significant at $\mathrm{p} \leq 0.05$; “-” means data not available; $\mathrm{n}=11$. 
input in an agricultural system) indicate that considerable Mississippi agriculture has improved $\mathrm{N}$ use efficiency over the period 1998 to 2008. In 2003 and 2006, N efficiency was low in Poland, and in 2000 and 2006 NUE was low in MS. The low NUE could be caused by unusual weather conditions. The summer of 2003 and 2006 were exceptionally hot and dry. The hot and dry weather, especially in Europe during the summer, resulted in high yield losses and low nutrient uptake, leading to lower nitrogen index use. Nitrogen index use depended on region; it was high in region Podcarpatian (78\%) and low in Silesia (72\%), but was the lowest in Lublin region $(42 \%)$ and in Lódź region (44\%). The efficiency of fertilizer $\mathrm{N}$ is frequently low, with often less than $50 \%$ of applied $\mathrm{N}$ taken-up by the crop [37,38]. Nitrogen use efficiency is an ambiguous term describing different aspects of nitrogen uptake and utilization by the crop. The first agronomical factor limiting $\mathrm{N}$ fertilizer use efficiency is the quantity of available phosphorus and potassium, which is required to reach the level of sufficiency for the crop grown. Extremely low rates of $\mathrm{P}$ and $\mathrm{K}$ fertilizers were the main reason for soil mining, negatively affecting harvested yields [39]. In some countries, like Poland, where soils are naturally poor in K [40], the main way to achieve the balance is constant application of sufficient amounts of $\mathrm{P}$ and $\mathrm{K}$ fertilizers.

Numerous studies have shown that $54 \%-72 \%$ of mineral nitrogen fertilizer applied was taken-up by the plant, $8 \%-21 \%$ is bound in soil organic matter, $2 \%-18 \%$ is lost to the atmosphere by denitrification, and only $2 \%$ $8 \%$ is lost by leaching [41]. Unfortunately, fertilizer sources are not utilized efficiently in agricultural systems, and plant uptake seldom exceeds $50 \%$ of the $\mathrm{N}$ applied $[42,43]$. To improve $\mathrm{N}$ and $\mathrm{P}$ use efficiencies, it is important to take measures at farm level because intervening in one step of the nutrient cycle may affect $\mathrm{N}$ and $\mathrm{P}$ run-off elsewhere. For example, covering slurry storage reduces direct ammonia emissions, but most of that ammonia is likely to volatilize soon after slurry application, unless low-emission techniques are applied [44]. It is difficult to be sure which part of fertilizer nitrogen is collected in the soil and which is lost to the environment. The answer may be obtained by measuring the nitrogen forms with the use of isotope methods so that the source of contamination could be traced back to the isotope used.

Phosphorus use efficiency during the 11 year period was higher in Mississippi than in Poland for all years (Figure 9), and this nutrient is much better used in MS than in Poland. Average values of phosphorus use in years 1998-2008 were 34\% for MS and 4.3\% for Poland. According to the literature $[45,46]$, the use of phosphorus from mineral fertilizers in the first year is equal $10 \%$ $20 \%$. Previous studies $[32,47]$, based on the field ex- periments on soils rich in phosphorus, showed that the $\mathrm{P}$ use from mineral fertilizers on soils with optimal phosphorus fertilization was only about $1 \%$ [32]. The $\mathrm{P}$ use from mineral fertilizers shows that these soils contained sufficient level of available P for cultivated plants. The use of $P$ may serve as the measurement of soil management [48]. The cost of fertilization has a real contribution to production cost and, therefore the knowledge of nutrients use has economic and ecological meaning. The efficient use of fertilizer $\mathrm{P}$ is important at least for two main reasons. First, there is a need to maintain and improve the $\mathrm{P}$ status of many soils for crop production for food, fibber, and bioenergy. Second, the transfer of soil P (derived from fertilizers and organic manure) is a major cause for eutrophication in surface waters [49]. The use of $\mathrm{P}$ from mineral fertilizers was always important for plant production, but in the last decade it became a source of potential risk to environmental contamination [50,51]. Although excessive phosphorus accumulation in the soil may have a negative influence on environment, leading to eutrophication [52-56], it should be noted that the relation between the phosphorus content in the soils and its leaching dynamics are still not yet understood. Sharpley [57] showed that the amount of P leached to surface waters is the function of plant growth system and of soil quality. Since phosphorus is one of the major nutrients for plant growth and crop production, methods of phosphorus applications that increase its efficiency as fertilizer and decrease its harmful influence to the environment are needed [58]. It was found that inefficient nutrient use and the concomitant nutrient enrichment of agroecosystems may contribute to agriculture's impact on aquatic systems [59]. It is estimated that European agriculture contributes from $40 \%$ to $80 \%$ of nitrogen $(\mathrm{N})$ and $20 \%$ to $40 \%$ of the P loading of surface waters [60].

\section{CONCLUSION}

Differences in predominant production systems result in different fertilizer sources, and therefore, nitrogen use efficiency. Intensive animal production such as confinement poultry results in excessive production of animal manure. Integrated farming system is a better approach for animal waste use and management, and have less dependency on external inputs. Mississippi and Poland had positive $\mathrm{N}$ and $\mathrm{P}$ balances, indicating that there was a surplus of $\mathrm{N}$ and $\mathrm{P}$, and the nutrient balance of $\mathrm{N}$ or $\mathrm{P}$ depended on the efficient use of each nutrient and type and source of fertilizer used. Nitrogen budget in Poland differs regionally and continentally due to production management methods and fertilizers efficiency. The lowest $\mathrm{N}$ surplus was below $30 \mathrm{~kg} \cdot \mathrm{ha}^{-1}$ reported in Dolnoslaskie (Lower Silesia) and Podkarpackie (Under Carphatian) provinces. On average $\mathrm{N}$ and $\mathrm{P}$ budgets in 
Mississippi during 1998 and 2008 reached $102 \mathrm{~kg} \cdot \mathrm{N} \cdot \mathrm{ha}^{-1}$ and $18.8 \mathrm{~kg} \cdot \mathrm{P} \cdot \mathrm{ha}^{-1}$, respectively, with nitrogen efficiency around $43 \%$. This research demonstrated the significance of $\mathrm{N}$ and $\mathrm{P}$ fertilizer management and their impact on agriculture production and environment health.

\section{ACKNOWLEDGEMENTS}

This join project was supported by the Organisation for Economic Cooperation and Development (OECD). The host institution was Crop Production Systems Research Unit, USDA-ARS, Stoneville, MS, USA. Dr. Gaj is thankful to Dr. Gretchen F. Sassenrath for support and for being the host scientist.

\section{REFERENCES}

[1] Cassman, K.G., Dobermann, A.M., Walters, D.T. and Yang, H. (2003) Meeting the cereal demand while protecting natural resources and improving environmental quality. Annual Reviews of Environment and Resources, 28, 315-358.

doi:10.1146/annurev.energy.28.040202.122858

[2] Heathwaite, A.L., Burt, T,P., Trudgill, S,T. and Burt, T.P. (1993) Overview-The nitrate issue. In: Burt, T,P., Heathwaite, A.L. and Trudgill, S.T., Eds., Nitrate: Processes, Patterns and Management, Wiley, Chichester, 3-21.

[3] Wiesler, F. and Armbruster M. (2009) The application of the $\mathrm{N}_{\min }$ soil test as an element of integrated nitrogen management strategies in agriculture. Fertilizers and Fertilization, 37, 50-58.

[4] Nielsen, R. (2005) Can we feed the world? Is these a nitrogen limit of food production?

http://home.iprimus.com.au./nielsen/nitrogen.html

[5] Owen, Tr. and Jurgens-Gschwind, S. (1986) Nitrates in drinking water: A review. Fertilizer Research, 10, 3-25. doi:10.1007/BF01073902

[6] Füleky, G. (2009) Downward movement of fertilizer nitrogen in Hungarian soils. Fertilizers and Fertilization, 37, 73.

[7] OECD. (2007) Gross nitrogen balances. Handbook. Organisation for Economic Co-operation and Development, Paris.

[8] Gross nutrient balance. http://www.eea.europa.eu/data-and-maps/indicators/gross -nutrient-balance-1 Verified on 10-24-2011.

[9] Methodologies for assessing soil nutrient balances: Macrolevel: Sub-Saharan Africa soil nutrient-balance study, FAO, 1983-2000.

http://www.fao.org/docrep/006/y5066e/y5066e06.htmVer ified on 10-24-2011

[10] Statistical Yearbook of Agriculture (2010) Verified on 10-24-2011.

http://www.stat.gov.pl/cps/rde/xbcr/gus/PUBL sy statisti cal yearbook agriculture 2010.pdf

[11] Bechmann, M., Eggestad, H.O. and Vagstad, N. (1998) Nitrogen balances and leaching in four agricultural catchments in south-eastern Norway. Environmental Pollu- tion, 102, 493-499. doi:10.1016/S0269-7491(98)80074-2

[12] IFASTATISTICS and IFADATA, Verified on 10-25-2011. http://www.fertilizer.org/ifa/HomePage/STATISTICS; www.fertilizer.org/ifa/statistics/ifadata/dataline.asp

[13] FAOSTAT, Verified on 10-25-2011. http://faostat.fao.org/default.aspx

[14] Tilman, D. (1999) Global environmental impacts of agriculture expansion: The need for sustainable and efficient practices. Proceedings of the National Academy of Sciences of the United States of America, 96, 5995-6000. doi:10.1073/pnas.96.11.5995

[15] Parris, K. (1998) Agricultural nutrient balanes as agrienvironmenal indictors: An OECD perspective. Environmental Pollution, 102, 219-225. doi:10.1016/S0269-7491(98)80036-5

[16] CSO. (2008) Statistical yearbook of agriculture and rural areas. Central Statistical Office, Warsaw.

[17] Olesen, J. and Bindi, M. (2002) Consequences of climate change for European agricultural productivity, land use and policy. European Journal of Agronomy, 16, 239-262. doi:10.1016/S1161-0301(02)00004-7

[18] Sample, E.C., Soper, R.J. and Racz, G.J. (1980) Reaction of phosphate fertilizers in soil. In: Khasawneh, F.E., Sample E.C. and Madison, K.E.J., Eds., The Role of Phosphorus in Agriculture, ASA, Stoneville, 263-310.

[19] McLaughlin, M.J., Alston, A.M. and Martin, J.K. (1988) Phosphorus cycling in wheat-pasture rotations. III Organic phosphorus turnover and phosphorus cycling. Australian Journal of Soil Research, 26, 343-353. doi:10.1071/SR9880343

[20] OECD. (2004) Agriculture, Trade and Environment: The Dairy Sector, Organisation for Economic Co-operation and Development, Paris.

[21] Öborn, I., Edwards, A.C., Witter, E., Oenema, O., Ivarsson, K., Withers, P.J.A., Nilsson, S.I. and Stinzing, R.A. (2003) Element balances as a tool for sustainable nutrient management: A critical appraisal of their merits and limitations within an agronomic and environmental context. European Journal of Agronomy, 20, 211-225. doi:10.1016/S1161-0301(03)00080-7

[22] OECD. (2001) Environmental indicators for agriculture: methods and results. Organisation for Economic Co- operation and Development, Paris, France.

[23] Oenema, O., Kros, H. and De Vries, W. (2003) Approaches and uncertainties in nutrient budgets: Implications for nutrient management and environmental policies. European Journal of Agronomy, 20, 3-16. doi:10.1016/S1161-0301(03)00067-4

[24] OECD. (2003) Environmental performance reviewsPoland, Organisation for Economic Co-operation and Development, Paris, France.

[25] Helsinki Commission. (2010) Helcom ministerial declaration on the implementation of the Helcom Baltic Sea Action Plan. HELCOM, Moscow.

[26] Peoples, M.B., Freney, J.R. and Mosier, A.R. (1995) Minimizing gaseous losses of nitrogen. In: Bacon, P.E., Ed., Nitrogen Fertilization in the Environment, Marcel Dekker, 
New York, 565-602.

[27] Fotyma, M. (2009) Monitoring of mineral nitrogen contents in soils of Poland. Fertilizers and Fertilization, 37, 108.

[28] Fotyma, M. and Igras, J. (2009) Contribiution of Polish agriculture to emmision of nitrogen and phosphorus compounds to the Baltic Sea, IUNG-PIB, Puławy, 331-348.

[29] DeLaune, R.D. and Jugsujinda A. (2003) Denitrification potential in Louisiana wetland receiving diverted Mississippi River water. Chemistry and Ecology, 19, 41-418. doi:10.1080/02757540310001618820

[30] Rick, S., Rick, H.H. and Twilley, R. (2003) Benthic and pelagic nutrient cycling in a costal watershed influenced by river diversions (Caernarvon, Louisiana). ERF Conference Proceedings, Seattle, 14-18 September 2003.

[31] Rankinen, K., Salo, T. and Rita, H. (2007) Simulated nitrogen leaching, nitrogen mass field balances and their correlation on four farms in south-western Finland during a period 2000-2005. Agriculture and Food Science, 16, 387-406. doi:10.2137/145960607784125348

[32] Gaj, R. (2008) Sustainable management of phosphorus in soil and plant in conditions of intensive plant production. Fertilizers and Fertilization, 33, 153.

[33] Lipiński, W. (2000) The soil pH and the nutrients content of polish soils as evaluated by the studies of Soil Test Laboratories. Fertilizers and Ferilization, 3, 89.

[34] Johnston, A. and Syers, J.K. (2006) Changes in understanding the behavior of soil and fertilizer phosphorus: Implications for their efficient use in agriculture. Proceedings of the International Fertilizer Society, York.

[35] Igras, J. (2002) The evaluation of phosphorus loses in polish agriculture. Fertilizers and Fertilization, 4, 275.

[36] Mander, U. and Forsberg, C. (2000) Nonpoint pollution in agricultural watersheds of endangered coastal seas. Ecological Engineering, 14, 317-324. doi:10.1016/S0925-8574(99)00058-0

[37] Raun, W.R. and Johnson, G.V. (1999) Improving nitrogen use efficiency for cereal production. Agronomy Journal, 91, 357-363. doi:10.2134/agronj1999.00021962009100030001x

[38] Wiesler, F. (1998) Comparative assessment of the efficacy of various nitrogen fertilizers. In: Rengel, Z. Ed., Nutrient Use in Crop Production, Food Products Press, New York, 81-114.

[39] Grzebisz, W. and Fotyma, M. (2007) Recommendations and use of potassium fertilizers in Central-Easern Europe (CEE). Proceedings of International Fertilizer Society, York, 24.

[40] Fotyma, M. (2003) Fertilizer use by crops in Poland. FAO, Rome, 44.

[41] Hahne, H.C.H., Kroontje, W. and Lutz, J.A. (1977) Nitrogen fertilization, I. Nitrate accumulation and losses under continuous corn cropping. Soil Science Society of America, 41, 562-567. doi:10.2136/sssaj1977.03615995004100030028x

[42] Parris, K. (2007) Agri-environmental performance in Poland. Recent trends and future outlook an OECD perspec- tive. Polish Society for Agronomy. Poznań.

[43] Cassman, K.G., Dobermann, A. and Walters, D. (2002) Agroecosystems, nitrogen-use efficiency, and nitrogen management. Ambio, 31, 132-140.

[44] Aarts, H.F.M., Biewinga, E.E. and Van Keulen, H. (1992) Dairy farming systems based on efficient nutrient management. Netherlands Journal of Agriculture Science, 40, 285-299.

[45] Fardeau, J.C., Guiraud, G. and Marol, C. (1997) Phosphate fertilization: The evolution of its reperesentation over the century. Scientific Representation in Agronomy and Plant Physiology, 117.

[46] Fotyma, M. and Mercik, S. (1995) Chemia Rolna PWN. Warszawa.

[47] Arora, S. (2011) Balanced Nutrition for Sustainable Crop Production. Verified on 10-24-2011. http://www.krishiworld.com/html/balanced fertilizer.htm

[48] Schnug, E., Rogasik, J. and Haneklaus, S. (2003) The utilization of fertilizer phosphorus with special view of organic farming. Landbauforsch Völkenrode (The Federal Agricultural Research Centre-Germany), 53, 1-25.

[49] Syers, J.K., Johnston, A.E. and Curtin, D. (2008) Efficiency of soil and fertilizer phosphorus use. Fertilizer and Plant Nutrition Bulletin 18, FAO, Rome.

[50] Lewis, D.R. and McGechan, M.B. (2002) A review of field scale phosphorus dynamics models. Biosystems Engineering, 82, 359-380. doi:10.1006/bioe.2002.0102

[51] Johnston, A.E. and Dawson, C.J. (2005) Phosphorus in agriculture and in relation to water quality. Agricultural Industries Confederation, Peterborough.

[52] Gburek, W.J., Sharpley, A.N., Heathwaite, L. and Folmar, G.J. (2000) Phosphorus management at the watershed scale: Modification of phosphorus index. Journal of Environmental Quality, 29, 130-144. doi:10.2134/jeq2000.00472425002900010017x

[53] Haygarth, P.M., Hepworth, L. and Jarvis, S.C. (1998) Form of phosphorus transfer and hydrological pathways from soil under grazed grassland. European Journal of Soil Science, 49, 65-72. doi:10.1046/j.1365-2389.1998.00131.x

[54] Jorgensen, K.L. and Borggaard, O.K. (1992) A preliminary investigation of sorption and mobility of phosphate in Danish spodosol. Acta Agriculturae Scandinavica, 42, 140.

[55] McDowell, R.W., Sharpley, A.N. and Kleinman, P.J.A. (2002) Integrating phosphorus and nitrogen decision management at watershed scales. Journal of American Water Resources Association, 38, 479-491. doi:10.1111/j.1752-1688.2002.tb04331.x

[56] Sharpley, A.N., Daniel, T.C. and Edwards, D.R. (1993) Phosphorus movement in the landscape. Journal of Production Agriculture, 6, 492-500.

[57] Sharpley, A.N., Ahuja, L.R., Yamamoto, M. and Mezel, R.G. (9181) The kinetics of phosphorus desorption from soil. Soil Science Society of American Journal, 45, 493496. doi:10.2136/sssaj1981.03615995004500030010x

[58] Frossard, E., Condron, L.M, Oberson, A., Sinaj, S. and 
Fardeau, J.C. (2000) Processes governing phosphorus availability in temperate soils. Journal of Environmental Quality, 29, 15-23. doi:10.2134/jeq2000.00472425002900010003x

[59] Fernall, D. (2011) Soil nutrient balances: Reviewing and developing to meet customer needs, executive summary, verified on 10-24-2011.

http://www.oecd.org/dataoecd/46/20/44793491.pdf

[60] Sharpley, A.N. and Withers, P.J.A (1994) The environmentally-sound management of agricultural phosphorus. Fertilizer Research, 39, 133-146. doi:10.1007/BF00750912 